\title{
AN ASSESSMENT OF THE FRAMEWORK FOR BUILDING A PRO BONO CULTURE AMONG LEGAL PRACTITIONERS IN NIGERIA
}

\author{
IFEANYI HENRY NNADI ESQ. LL. B, PGDBA, PDE, MICTEL, LL.M, BL, FIPMA \\ (Principal Partner, Ifeanyi Nnadi and Company, Sokoto, Nigeria - 08066954034; \\ 08057735552; ifeanyinnadi@yahoo.com)
}

\begin{abstract}
Pro bono legal services are professional services rendered by lawyers or other legal experts ${ }^{1}$ to indigent and disadvantaged litigants in the society for the public good id est, in order to promote a just and equitable society. It is a subset of the principle of equal access to justice and is based on the assumption that the poor requires but cannot access justice because they lack the financial means. Using the doctrinal approach, this discourse assesses the existing legal and administrative framework for pro bono engagement by lawyers in Nigeria with a view to identifying areas of improvement. Having identified possible areas of improvement, recommendations are proffered on legislative and administrative measures towards improving the level of engagement in pro bono legal services by legal practitioners in the country.
\end{abstract}

Keywords - Pro bono; free legal services; access to justice; human rights; legal aid; legal aid council; legal practitioners

\footnotetext{
${ }^{1}$ Legal expert in this context refer to paralegals, law students, law clinics and NGOs who are also recognised pro bono legal service providers by virtue of extant international and regional legal instruments and the Legal Aid Act.
} 


\section{INTRODUCTION}

Equality before the law is one of the cardinal principles of justice administration in Nigeria. This principle presupposes that the law should give equal protection to the rich and the indigent, the educated and the illiterate, the weak and the powerful, the privileged and the disadvantaged of the society. This principle is amply illustrated by the lady justicia which remains the symbolic embodiment of the legal force in most modern legal systems including Nigeria. Two of her prominent features are a blindfold and a balance which is illustrative of the idea of equality before the law. In the famous lines of Reginal Heber Smith, "without equal access to the law the system not only robs the poor of their only protection, but places in the hands of their oppressors the most powerful and ruthless weapon ever invented."i Access to justice is a constitutional right that is embedded in the doctrine of fair hearing contained in section 36 of Nigeria's Constitution. ${ }^{2}$ The right is more explicit in criminal cases where every person charged before a court of law is entitled to adequate facilities for his defence and any legal practitioner of his own choice. However, equality before the law will remain a mirage when the indigent, the uneducated, the weak and the disadvantaged members of the society do not have access to the means for seeking legal redress or defending themselves from legal actions whether civil or criminal. This is the case with Nigeria where millions of its citizens are penurious and educationally disadvantaged.

Access to justice stresses the need for the means and procedures for accessing justice to be available to all and sundry irrespective of their pecuniary position or their educational or social standing in the society. Legal practitioners are the professionals bestowed with the techniques and procedures for accessing justice. They are trained to represent clients in court, give legal advice, prepare legal documents and assist with alternative means of dispute resolution such as arbitration, mediation and conciliation. When a person does not have the means of hiring a legal practitioner or does not have access to a legal practitioner by reason of educational, geographical or any other disadvantage it can be safely said that such a person lacks access to justice. This underscores the need for legal practitioners to provide pro bono services for indigent and disadvantaged members of the society.

The pro bono culture among legal practitioners in Nigeria is relatively low. While the Bar in a number of advanced countries have a booming tradition of rendering free legal services to indigent litigants in order to promote public good, majority of lawyers in Nigeria have lost touch with the legal needs of indigent members of the society. Aside the requirement for a history of pro bono legal services for applicants for the rank of Senior Advocate of Nigeria, which compels potential applicants of the prestigious rank to do pro bono cases, only a small percentage of legal practitioners in the country engage in pro bono legal services as a routine. This percentage does not however exclude potential applicants for the rank of Senior Advocate of Nigeria who do pro bono work as a purely altruistic practice. Though a number of considerations are involved in a lawyer or a law firm's decision to undertake or not to undertake pro bono legal services, the principal factor is not farfetched; there is no comprehensive legal framework to secure obligatory involvement in pro bono legal services among legal practitioners in Nigeria. Even in the sphere of ethics, there are no code of values that mandate legal practitioners in the country to undertake pro bono legal services as a social responsibility.

\footnotetext{
${ }^{2}$ See Constitution of the Federal Republic of Nigeria, 1999 (as amended). Section 36(1) and (6).
} 
In countries with booming culture of pro bono among its legal practitioners, there are well structured legal framework to secure obligatory involvement in pro bono services among legal practitioners carrying out their trade in those countries. In South Korea for instance, the Rules of its bar association requires lawyers who practice in its jurisdiction to undertake at least thirty hours of pro bono legal services. This period may be reduced to twenty hours by the local branch of the bar association and those with reasonable excuses for their inability to fulfill the requirement of pro bono work may pay specified cash equivalent of the man hours. ${ }^{3}$ In the United States, the Rules of Professional Conduct for the country's bar association mandates legal practitioners practicing in the country to contribute not less than 50 hours of pro bono legal services per year. This is however subject to lesser or greater periods that may be provided by bar associations of individual states. ${ }^{4}$ However, the absence of a comprehensive legal framework for pro bono services among legal practitioners in Nigeria should not be interpreted to mean the absence of an initiative for pro bono legal services in the country. This discourse will thus attempt to assess the extant initiatives for ensuring that legal practitioners in the country engage in pro bono legal services.

\section{CONCEPT AND HISTORICAL DEVELOPMENT OF PRO BONO LEGAL SERVICES}

Pro bono is a short form of the Latin phrase pro bono publico which means "for the public good." The term generally refers to services that are rendered by a professional either for free or at a significantly reduced cost to the recipient of the service. ${ }^{\text {ii }}$ Within the legal context, pro bono involves uncompensated legal services performed for the public good. The concept originally encompasses a wide range of activities, including law reform efforts, participation in bar associations and civic organisations, and individual or group representation. Clients who receive such assistance also span a broad range of individuals and groups including poor people, non-profit organisations, ideological or political causes, and friends, relatives or employees of the legal practitioner rendering the service. ${ }^{\text {iii }}$

The term, "pro bono" is used primarily in the legal profession, as lawyers have an obligation by the ethical standards of their profession to charge reasonable rates for services rendered to clients and to serve the interest of the public by providing free legal services to indigent litigants. The lawyer who renders pro bono legal services is thought to be imparting a benefit for the greater good of the society instead of working for the usual for-profit motive (Tardi, 2019). Pro bono legal service is viewed as a lawyer's obligation to ensure the fair administration of justice without monetary rewards. ${ }^{\text {iv }}$ Its devotion to providing free assistance to indigent litigants sets the legal profession apart from others as no other field or profession has the obligation to perform pro bono services incorporated into its codes. ${ }^{\mathrm{v}}$ Pro bono services is part of the wider concept of access to justice and seeks to ensure that legal services are provided at no cost for indigent and disadvantaged litigants due to the fact that they do not have sufficient means or that the interest of justice so requires.

It has been argued that pro bono legal services relates to legal work done for the public good at below market rates for recipients who either cannot afford to pay or who would not pay due to the scarcity of financial resources or the limited value placed on the relevant services or who would otherwise not be able to source such services elsewhere in the open market. ${ }^{\mathrm{vi}}$ The rates for legal services in Nigeria are relatively low compared to most advanced

\footnotetext{
${ }^{3}$ See Korean Bar Association Rules on Pro Bono. Article 3; Attorney-at-Law Act, 1962 (as amended). Article 27.

${ }^{4}$ See American Bar Association Model Rules of Professional Conduct, 1983. Rule 6.1.
} 
countries yet remain unaffordable to most litigants. Describing pro bono legal services as legal services undertaken for considerations below market rates may therefore not be workable within the Nigerian context even though it may be applicable to some other jurisdictions. Pro bono legal services in Nigeria involve no financial reward in the form of professional fees by the recipient for the services rendered. Although a legal practitioner who renders pro bono legal services is at liberty to charge reasonable stipends to cover transportation and filing costs and his efforts will still be within the ambit of pro bono legal services. ${ }^{5}$

The principle that law should apply equally to all persons irrespective of their ability to pay has its roots in $15^{\text {th }}$ century England. However, until the $19^{\text {th }}$ century this concept was only applied to specific classes of cases (Bellusci, 2014). Medieval canon laws contained a number of injunctions to legal practitioners to represent indigent litigants in the society. ${ }^{\text {vii }}$ The English Parliament of this period also made laws allowing poor litigants to file cases in court without the payment of court fees and requiring judges to assign such poor litigants to lawyers who would handle the mater pro bono. ${ }^{\text {viii }}$ Pro bono practices were also common among legal practitioners in the United States during its early years. As far back as 1770, a few years before the American Revolution, John Adams - a foremost American lawyer and statesman who later became the country's second president - took on the pro bono defense of some British soldiers who were implicated in the Bolton Massacre. As at the time of the American independence, pro bono was already established as an accepted practice in the country. ${ }^{\mathrm{ix}}$

In Nigeria, lawyers have been providing pro bono legal services for a very long time. Pro bono representation has become an important part of the legal profession in the country and is adopted within a large spectrum of cases especially criminal cases. However, the growth of an organised method of pro bono services by lawyers and law firms in the country is a relatively recent occurrence. ${ }^{\mathrm{x}}$ The first attempt at creating a structure for pro bono legal services in the country was with the establishment of the Nigerian Legal Aid Association in 1974. The Association was made up of legal practitioners who made it a duty to provide legal services for indigent litigants in the country. It was this Association that metamorphosed into the Legal Aid Council of Nigeria with the promulgation of the Legal Aid Decree No. 56 of 1976. The decree went through a series of amendments meant to review the limits of the provision of legal aid services by the government and was later codified into the Legal Aid Council Act in 2004. ${ }^{6}$ It was reenacted as the Legal Aid Act in 2011 and the new Act immensely increased the powers of the Legal Aid Council especially with respect to giving legal assistance to litigants in civil cases. ${ }^{7}$

\section{LEGAL FRAMEWORK FOR PRO BONO LEGAL SERVICES IN NIGERIA}

As mentioned earlier, there is no comprehensive legal framework to secure obligatory involvement in pro bono legal services among legal practitioners in Nigeria. However there are pockets of legislations that make provisions for legal assistance to the indigent and disadvantaged members of the society or regulate such assistance. These legislations include

\footnotetext{
${ }^{5}$ See Philips Chindo v. Likita Dangana (2016) LPELR - 40177 (CA).

${ }^{6}$ See Cap L9, Laws of the Federation of Nigeria, 2004.

${ }^{7}$ See the Legal Aid Act, 2011. Sections 1(3) and 8; also see the explanatory memorandum to the Legal Aid Act, 2011.
} 
some international and regional human rights instruments signed and ratified by Nigeria that make elaborate provisions on access to justice for indigent and disadvantaged litigants. They also include some local legislations foremost of which is the Constitution which remains the country's basic norm and forms the underlying basis for its legal system and to which every other law must be in conformity with to derive validity.

\section{A. International Human Rights Instruments}

The right to access to justice is in the class of human rights. Thus some international human rights treaties are clearly worded to incorporate access to free legal services. Article 14(3)(d) of the International Covenant on Civil and Political Rights ${ }^{8}$ provides for the right of a litigant to have legal assistance assigned to him in any case where the interest of justice so requires and without payment where he does not have the means to pay. Article 14 of the Convention against Torture and Other Cruel, Inhuman and Degrading Treatment or Punishment ${ }^{9}$ urges State parties to the Convention to ensure that their legal systems provide means for victims of torture to obtain redress, adequate compensation and rehabilitation. Article 37 of the Convention on the Rights of the Child ${ }^{10}$ urges State parties to ensure that every child who is detained has prompt access to legal and other appropriate assistance.

\section{B. Regional Human Rights Instruments}

The African Commission on Human and Peoples' Rights, of which Nigeria is a member, has adopted a series of principles, declarations and guidelines governing access to free legal services. ${ }^{\mathrm{xi}}$ Although these are non-binding legal instruments, they provide persuasive guidance on the role of the government, non-governmental organisations, lawyers and judicial officers in the provision of free legal services to indigent and disadvantaged litigants. The Principles and Guidelines on the Right to a Fair Trial and Legal Assistance in Africa outlines the essential elements of a fair trial to include entitlement of every party to the proceedings to legal representation or representation by other qualified persons. It further outlines the principles applicable to arrest and detention to include necessary facilities for communicating with a lawyer and prompt access to legal representation. It enjoins States parties to ensure equal access to lawyers by all persons and to provide legal assistance for indigent litigants in both civil and criminal cases. ${ }^{11}$ The Resolution on the Right to a Fair Trial and Legal Aid in Africa otherwise known as the Dakar Declaration makes it a duty for governments to provide legal assistance to indigent litigants who are unable to afford legal services. This is in order to make the right to fair trial promoted by the Declaration more effective. $^{12}$

The Lilongwe Declaration on Accessing Legal Aid in the Criminal Justice System in Africa is one of the most comprehensive regional legal instruments on pro bono legal services in Africa. It recognises legal assistance as a basic human right and makes it a responsibility for governments to adopt measures and allocate funds to ensure effective and transparent delivery of legal aid to the poor and vulnerable members of the society and by so doing

\footnotetext{
${ }^{8}$ The ICCPR was adopted by the United Nations in 1966 and Nigeria ratified it on $29^{\text {th }}$ July, 1993.

${ }^{9}$ Nigeria became a signatory to this 1985 Convention on $28^{\text {th }}$ July, 1988 and ratified it on $28^{\text {th }}$ June, 2001.

${ }^{10}$ The Convention was adopted by the United Nations in 1989 and Nigeria ratified it on $16^{\text {th }}$ April, 1991.

${ }^{11}$ See the Principles and Guidelines on the Right to a Fair Trial and Legal Assistance in Africa, 2003. Sections $A(2)(f), G, M(2)(e) \&(f)$.

${ }^{12}$ See the Dakar Declaration and Recommendations on Right to Fair Trial in Africa, 1999 adopted in the Resolution.
} 
empower them to access justice. The Declaration highlights the need to sensitise all stakeholders in the criminal justice sector of the crucial role legal assistance plays in the development and maintenance of a just and fair criminal justice system. It emphasises the provision of legal assistance for indigent litigants at all stages of the criminal justice process from investigation to appeal. ${ }^{13}$ Though the Lilongwe Declaration relates to provision of legal assistance in criminal matters, it recognises the right to redress for human rights violations and enjoins governments to provide legal assistance for persons who seek such redress. It also recognises and encourages non-formal alternatives to dispute resolutions. The Declaration enjoins lawyers in the private bar to see the provision of pro bono legal services as an important professional duty and enjoins bar associations to provide substantial moral and logistical support to lawyers offering pro bono legal services. ${ }^{14}$

\section{The Constitution}

The Constitution of the Federal Republic of Nigeria ${ }^{15}$ is the grundnorm of the country. It is the highest legal instrument in the country and any other legal instrument that is inconsistent with it is null and void to the extent of such inconsistency. ${ }^{16}$ The Constitution makes provisions for some fundamental rights in its Chapter IV one of which is the right to fair hearing contained in section 36 of the Constitution. Though access to justice, which features pro bono legal representation as one of its attributes, is a constitutional right that is embedded in the right of to fair hearing, there are no clear provisions in the Constitution on the provision of legal representation for indigent litigants save in criminal matters. Section 36(6)(b) provides that every person charged with a criminal offence shall be entitled to adequate time and facilities to prepare his defence. It is asserted that facilities in the context of section 36(6)(b) includes legal representation. This assertion is supported by the fair hearing provisions in the International Covenant on Civil and Political Rights and the African Commission on Human and Peoples' Rights' Principles and Guidelines on the Right to a Fair Trial and Legal Assistance. Both instruments recognise the right to legal assistance as a fundamental right of an accused person and enjoin State parties to provide such assistance in any case where the interest of justice so requires and without payment by the accused where he does not have sufficient means. ${ }^{17}$

By section 36(6)(c) an accused person has the right to legal representation by a legal practitioner of his own choice. This is not in conflict with the provision of legal assistance for an accused person who is not represented by a lawyer but gives such accused the choice to accept or reject such representation.

By the provision of section 12 of the Constitution, no treaty between the Federation and any other country shall have the force of law except to the extent to which such treaty has been enacted into law by the National Assembly. This means that all international and regional legal instruments relating to pro bono service provision for indigent and disadvantaged litigants do not have the force of law unless they are reenacted by the National Assembly or incorporated into laws made by the National Assembly. However, most of the

\footnotetext{
${ }^{13}$ See Lilongwe Declaration, 2004. Paragraphs $1-3$.

${ }^{14}$ See Lilongwe Declaration. Paragraphs 4, 5 \& 8.

${ }^{15}$ See CFRN, 1999 (as amended by the $1^{\text {st }}, 2^{\text {nd }} 3^{\text {rd }}$ and $4^{\text {th }}$ Alteration Acts.

${ }^{16}$ See CFRN. Section $1(3)$.

${ }^{17}$ See the International Covenant on Civil and Political Rights. Article 14(3)(d) and the African Commission on Human and Peoples' Rights Principles and Guidelines. Section G.
} 
international legal instruments mentioned above have been incorporated into Nigerian legislations. ${ }^{18}$ Also the regional instruments mentioned above, though still of persuasive authority, were made pursuant to the powers of the African Commission on Human and Peoples' Rights contained in the African Charter on Human and Peoples' Rights which has been domesticated in Nigeria. ${ }^{19}$

\section{Legal Aid Act}

The Legal Aid Act is the statute that established the Legal Aid Council of Nigeria, a federal government agency under the supervision of the Federal Ministry of Justice. The Council is saddled with the responsibility of giving legal aid and advices to indigent litigants in the country to enable them access justice in accordance with the Constitution. The Council provides legal aid and advices to indigent litigants in certain class of criminal cases and in civil cases for accidents and employee compensations, breach of fundamental rights and civil remedies for criminal wrongs. ${ }^{20}$ Indigent litigants by virtue of the Act are persons whose income is below the national minimum wage but persons whose income exceeds the national minimum wage may be given legal aid in exceptional circumstances. ${ }^{21}$

The concept of legal aid in Nigeria can be said to have been conceived in 1961 when the then Chief Justice of the country, Sir Adetokunbo Ademola, remarked during the African Conference on the Rule of Law held in Lagos that the constitutional right to fair hearing was meaningless if the financial aspect of access to justice was ignored. This was the first official public acknowledgement of the need for legal assistance for indigent litigants in the country. This led to a draft Legal Aid and Advice Bill prepared by the then Attorney-General of the Federation, Dr. T. O. Elias to be sent to the Parliament. Unfortunately the Bill did not see the light of day due to the Civil War of 1967 - 1970. However, the efforts of the Nigerian Legal Aid Association later culminated in the promulgation of the Legal Aid Decree No. 56 (later Act) of 1976 which metamorphosed into the legal Aid Act of 2011. ${ }^{\text {xii }}$

Section 14 of the Act empowers the Legal Aid Council to prepare and maintain a panel of legal practitioners willing to give legal aid to indigent litigants. Such legal practitioners normally render their professional services to indigent litigants through the Council either strictly pro bono or for gratuitous stipends provided by the Council. However the gratuitous stipends offered by the Council to private legal practitioners in their panel of pro bono service providers are too meager forcing majority of legal practitioners on the panel to render their professional services completely free. The Council regulates the provision of pro bono legal services by private legal practitioners in their panel. By section 14(3), staff of the council

\footnotetext{
${ }^{18}$ The Provisions of the International Convention the Rights of the Child are incorporated in the Child's Rights Act, Cap C50, Laws of the Federation of Nigeria, 2004; the provisions of the African Charter on Human and Peoples' Rights is modeled after the International Covenant on Civil and Political Rights which has become a domestic law in Nigeria with the passing of the African Charter on Human and Peoples' Rights (Ratification and Enforcement) Act, Cap A9, Laws of the Federation of Nigeria, 2004 while part of the provisions of the International Convention against Torture and other Cruel, Inhuman and Degrading Treatment or Punishment have been incorporated into the recently passed Anti-Torture Act, 2017. Also the fundamental rights provisions in Chapter IV of the Constitution are modeled after the International Covenant on Civil and Political Rights. It should be noted that not all the pro bono provisions of these international instruments were domesticated.

${ }^{19}$ See Cap A9, LFN. Articles $30-45$.

${ }^{20}$ See section 8 of the Legal Aid Act, 2011 and the explanatory memorandum to the Act.

${ }^{21}$ See Legal Aid Act. Section 10.
} 
may exclude the name of a legal practitioner from the panel due to his conduct or the conduct of a member of his firm in any previous matter assigned to him or his firm or due to his general professional conduct. Any legal practitioner aggrieved by such exclusion may refer the matter to the Director-General of the council and if he is not satisfied with the decision of the Director-General he may appeal to the Council's Governing Board.

The Legal Aid Council is empowered to review the panel of legal practitioners rendering pro bono legal services on its behalf on an annual basis. Only legal practitioners who have paid their annual professional practicing fees are entitled to have their names on the panel. The Council is also empowered to keep record of and monitor all pro bono cases handled by legal practitioners on behalf of indigent litigants even if such legal practitioners are not on its panel of pro bono service providers. Any legal practitioner who accepts to handle any civil or criminal matter on pro bono basis for an indigent litigant is therefore required by the Act to register such matter with the Council. The Council may also direct corps lawyers to render pro bono services to indigent litigants as part of their community development scheme. ${ }^{22}$

\section{E. Rules of Professional Conduct for Legal Practitioners}

The Rules of Professional Conduct for Legal Practitioners is a set of rules of ethical conduct that regulates the practice of law in Nigeria by legal practitioners. The Rules are made by the General Council of the Bar pursuant to powers conferred by the Legal Practitioners Act. ${ }^{23}$ Though the Rules does not make it mandatory for legal practitioners to engage in pro bono legal services as obtainable in order jurisdiction, it however makes provision for the regulation of pro bono legal services in criminal matters. By section 38 of the Rules a lawyer assigned to represent an indigent accused person shall not refuse to do so except for substantial reason. Where he defends such accused he shall exert his best effort towards the defence. Rules $14-25$ dealing with a lawyer's relationship with clients, Rules 28 - 29 dealing with employment of additional lawyer by the client and change of lawyer and Rules $30-37$ dealing with a lawyer's relationship with the courts are also applicable ethics when a legal practitioner is handling a pro bono matter.

\section{F. Guidelines for the Conferment of the Rank of Senior Advocate of Nigeria.}

The rank of Senior Advocate of Nigeria is a priviledge conferred pursuant to section 5 of the Legal Practitioners Act on legal practitioners who have achieved distinction in the practice of law in Nigeria. When such priviledge is conferred, the recipient has the exclusive right to sit at the inner bar or, where there are no facilities for the inner bar, the front roll of seats in all courts in Nigeria. The recipient of the rank also has the exclusive right to mention motions or matters meant for mention, in which he is appearing, out of turn.

The Guidelines for the Conferment of the Rank of Senior Advocate of Nigeria are made by the Legal Practitioners Privileges Committee ${ }^{24}$ pursuant to its powers conferred by the Legal Practitioners Act. The Guidelines are meant to regulate the conferment of the rank. ${ }^{25}$

\footnotetext{
${ }^{22}$ See Legal Aid Act. Sections 15, 16 \& 18(1).

${ }^{23}$ See the Legal Practitioners Act, Cap L11, Laws of the Federation, 2004. Section 1(1); the present Rules of Professional Conduct were made on $2^{\text {nd }}$ January, 2007.

${ }^{24}$ The Committee is saddled with the responsibility of conferring the rank of Senior Advocate of Nigeria on qualified applicants and regulating the conferment of the rank.

${ }^{25}$ See Cap L11, LFN. Section 5(3) \& (7).
} 
Journal DOI: www.doi.org/10.46654/SJALR

By Regulation 19(7)(c) of the current Guidelines ${ }^{26}$ an applicant for the rank of Senior Advocate of Nigeria must be involved in the conduct of at least three pro bono cases in order to qualify for conferment of the rank. Applicants are therefore requested to provide evidence of pro bono legal services along with their application. Applicants who apply as academics are however exempted from this criterion. Similar provision is contained in section 18(2) of the Legal Aids Act but that section restricts the three pro bono cases to the legal year preceding the date of application.

\section{ROLE OF THE BAR IN THE PROVISION OF PRO BONO LEGAL SERVICES}

The Bar in Nigeria has a major role to play in the provision of pro bono legal services for indigent and disadvantaged litigants in the country and the building of the culture of pro bono among its members. The Lilongwe Declaration enjoins bar associations in Africa to provide substantial moral, professional and logistical support to lawyers who provide legal assistance to indigent litigants. In countries where mandatory pro bono requirement cannot be imposed, bar associations are enjoined to strongly encourage their members to do pro bono work. ${ }^{27}$ In many African countries, including Nigeria, the government has limited capacity for legal assistance to indigent litigants either due to financial inadequacy or shortage of manpower or both factors. Even when non-governmental organisations complement the efforts of the government, the cooperation of the bar is needed by these organisations. This underscores the prominent role of the organised bar in the provision of pro bono legal services.

Aside the mandatory requirement of evidence of pro bono legal services for applicants for the rank of Senior Advocate of Nigeria, there is no law that requires the mandatory provision of pro bono legal services by lawyers in Nigeria. However, in 2009 the Nigerian Bar Association took some steps towards encouraging pro bono legal services among its members by making the Pro Bono Declaration. The Declaration required members to commit to providing more than 20 hours or three days of pro bono legal services for each lawyer in a year or, in the case of law firms, institutions or other groups of lawyers, an average of more than 20 hours per lawyer in a year. Another Declaration was made in 2015 with the new Declaration increasing the required amount of pro bono legal services to at least five indigent individuals, group of persons or communities in a year. The new Declaration also requires that pro bono legal services be carried out with the same quality of representation as fee paying clients and in a manner upholding the applicable ethical norms and standards.

\section{ROLE OF NON-GOVERNMENTAL ORGANISATIONS IN THE PROVISION OF PRO BONO LEGAL SERVICES}

A high percentage of pro bono legal services in Nigeria are donor funded. NonGovernmental Organisations (NGOs), especially foreign-based or foreign-aided organistions, have played prominent roles in pro bono legal service delivery in Nigeria. This is not only common to Nigeria but to most countries of Africa. It was in recognition of the important role played by NGOs in the provision of pro bono legal services that it was recognised as one of the legal aid service providers under the Lilongwe Declaration. With the absence of mandatory requirement for pro bono legal services for Nigerian lawyers and since the understaffed Legal Aid Council cannot deal with the large number of indigent litigants, especially in criminal matters, a bulk of the work of pro bono legal services have been left for

\footnotetext{
${ }^{26}$ The current Guidelines were made in August, 2018; see FRN official Gazette No. 12 Vol. 105, 2018.

${ }^{27}$ See Paragraph 8 of the Lilongwe Declaration.
} 
Journal DOI: www.doi.org/10.46654/SJALR

NGOs. The Justice Development and Peace Commission, the MacArthur Foundation, the International Federation of Women Lawyers, the Human Rights Law Service and the Open Society for Justice Initiative, to mention only a few, are some NGOs that have been prominent in the provision of pro bono legal services in Nigeria.

There are many other NGOs operating in the country that provide legal aid and assistance to indigent litigants, particularly in the human rights area. While some NGOs have staff of only a few lawyers, others retain the services of external counsel to provide legal aid and assistance to indigent clients on their behalf yet some others have a retinue of qualified lawyers and provide elaborate legal aid and assistance in a well structured manner. Although there are a number of legal services NGOs operating in the country, demand tends to exceed supply, especially in the rural regions. The number of lawyers available for legal assistance is often inadequate to meet the numerous legal assistance requests from indigent litigants. ${ }^{\text {xii }}$ Other NGOs that are linked with pro bono service provision in the country are the Institute of Human Rights and Humanitarian Law, Open Society Foundation, Basic Rights Counsel Initiative, Legal Defence and Assistance Project, the Women Aid Collective, the Prisoners Rehabilitation and Welfare Action and more recently the Justice Research Institute LTD GTE in collaboration with the Open Society Initiative of West Africa (through the Pro Bono Clearing House) among others. The Legal Aid Council is empowered by the Legal Aid Act to maintain a register of NGOs providing legal aid and assistance on pro bono basis to indigent litigants. ${ }^{28}$

\section{RECOMMENDATIONS}

\section{A. Mandatory Pro Bono Legal Services for Legal Practitioners in Nigeria}

The Lilongwe Declaration enjoins bar associations, law licensing agencies or the government to make pro bono legal services mandatory for lawyers where they have such option. The current level of pro bono participation among legal practitioners in Nigeria is low. This leaves many indigent litigants unable to access lawyers in a country having the largest number of legal practitioners in Africa. Meanwhile the Legal Aid Council is seriously understaffed and unable to deal with the large number of litigants in the country that need legal assistance. The Council has severally acknowledged their inability to meet the increasing need of free legal services in Nigeria (United Nations Office on Drugs and Crime, 2011; Latham and Walkins LLP (2015) ${ }^{\text {xiv }}$ This puts the organised bar in Nigeria in a precarious position with respect to pro bono service provision. It is high time the General Council of the Bar took the option of making pro bono legal services mandatory as opposed to voluntary for legal practitioners in Nigeria. This can be done by either reviewing the existing Rules of Professional Conduct to incorporate mandatory pro bono services or making a separate Rules of Pro Bono applicable to all lawyers. The mandatory provision on pro bono legal services may be modeled after the Mandatory Continuing Professional Development contained in the current Rules of Professional Conduct.

\section{B. Motivation of Legal Practitioners Who Undertake Pro Bono Legal Services}

As the name suggests, pro bono legal services are undertaken for the public good. Financial reward is therefore not a consideration in rendering pro bono services. However, there are other ways legal practitioners who render pro bono services to indigent and

\footnotetext{
${ }^{28}$ See section 17(1) of the Legal Aid Act, 2011.
} 
Journal DOI: www.doi.org/10.46654/SJALR

disadvantaged litigants can be motivated without the necessity for financial rewards. The leadership of the Nigerian Bar Association should fashion out schemes by which lawyers and law firms that have distinguished themselves in pro bono legal service provision are recognised and encouraged for their efforts. Non-Governmental Organisations involved in pro bono service provision could also come together or collaborate with the Legal Aid Council to organise award ceremonies where lawyers that have distinguished themselves in the rendering of pro bono services are recognised and given awards. There is presently no framework for recognising distinction in pro bono services in Nigeria aside its being a criterion for the award of the rank of Senior Advocate of Nigeria. However, not all lawyers involved in pro bono service provision may be interested in applying for the distinguished rank, a venture which is time, energy and resource consuming. Other forms of reward systems are therefore advocated to motivate legal practitioners in Nigeria to engage in pro bono services.

\section{Incorporation of Pro Bono into the Curriculum of Legal Education}

The curriculum for legal education in Nigeria should be reviewed to incorporate the principles, practice and ethics of pro bono service delivery as presently applicable to other salient issues like Alternative Dispute Resolution, professional ethics, law office management, matrimonial causes and election petitions. This will help create an understanding of the importance of pro bono legal services in the lawyer from the budding stage and prepare him for a life-time practice of a pro bono culture in the course of his legal practice. It may be introduced as a topic in any related core subject of the university education or incorporated into Professional Ethics and Skills at the Bar Part II stage of Law School education.

\section{Promotion of Pro Bono Enlightenment}

Non-governmental organisations like the Pro Bono Clearing House, a joint project of the Justice Research Institute LTD GTE and the Open Society Initiative of West Africa in collaboration with the Nigerian Bar Association among other NGOs have been at the forefront of enlightenment campaign to lawyers on the importance of a pro bono culture. In 2015 the NBA, through its Pro Bono Declaration, committed to advocating and promoting the recognition of pro bono services within the profession as part of lawyers' ethical standards and obligations. This commitment has however remained hypothetical as successive leaderships of the Bar have failed to implement it since 2015. The NBA, as a matter of urgency, needs to engage legal practitioners within the country on the importance of making individual commitments to the Pro Bono Declaration of the Association and building a culture of pro bono in their legal practice. The engagement should also emphasise the need for lawyers in the country to bridge the gap between the demand and supply for pro bono legal services. The engagement should, as a first step, begin with the Bar Conference which remains the largest gathering of lawyers in the country and should continue in the form of workshops, seminars and viva voce.

\section{E. Removal of Filing Fees for Pro Bono Matters}

One salient feature of pro bono practice in Nigeria is that it is more common among the younger breed of lawyers, though with the exception of those seeking for the rank of Senior Advocate of Nigeria. Filing fees for pro bono cases has been a challenge for lawyers, especially in civil cases and appeals to appellate courts. This is more so considering the financial position of the class of lawyers who mostly undertake pro bono cases. Lawyers who 
Journal DOI: www.doi.org/10.46654/SJALR

sacrifice their fees for services rendered for the good of the public often find it burdensome to also sacrifice their personal funds in paying for the filing of court processes. The heads of courts should facilitate the waiver of filing fees for lawyers who present evidence that they are undertaking a matter pro bono.

\section{F. Adequate Coordination of Pro Bono Legal Services}

The Legal Aid Council is the body statutorily empowered to coordinate pro bono cases in Nigeria. This is so if the wording of section 18(1) of the Legal Aid Act is anything to go by. As noted earlier, the Council is short-staffed. It was once reported that the Council had only 280 full-time lawyers in its service, a number that was grossly inadequate to cover all the thirty-six States of the federation and the Federal Capital Territory considering the number of awaiting trial inmates alone at the time which stood at 39, 577 (Latham and Walkins LLP, 2015). ${ }^{29}$ How this situation has improved remains an issue that may take a similar or even greater length as this discourse but the fact remains that the Legal Aid Council is inadequately staffed. It should be noted that the website of the council presently lists its staff strength to be 230 lawyers. ${ }^{\mathrm{xv}}$ The Legal Aid Council obviously do not have the resource and manpower to coordinate pro bono legal services provided by lawyers in the country if the capacity of pro bono legal services is to be increased as advocated in this discourse. The NBA has a major role to play in this regards. The various branches of the NBA should be made to coordinate the participation of their members in pro bono legal services through Pro Bono Committees. The National Pro Bono Centre proposed in the 2015 Pro Bono Declaration should be the central coordinating body to which the 125 branches of the NBA should send reports of pro bono work by members. The reports should then be forwarded to the Council by the National Pro Bono Centre. The Council may however continue to directly coordinate pro bono services rendered by lawyers in its panel. All these should be incorporated in a revised Legal Aid Act which should clearly define the scope and limits of acceptable pro bono legal services.

\section{CONCLUSION}

As rightly pointed out in the Pro Bono Declaration of the Nigerian Bar Association, the absence of access to justice and legal representation undermines public confidence in the government and judicial institutions. It is inconsistent with the tenets of a democratic society. It is important that justice be accessible to all irrespective of natural privilege or pecuniary standing. Indigent and disadvantaged litigants have legal needs as much as their affluent and middleclass counterparts. Their needs transcend the spheres of advocacy, legal drafting, and alternative dispute resolution. The need for legal representation for indigent and disadvantaged litigants in the society cannot be overemphasised. It is a part and parcel of the concept of access to justice and as such a basic element of the rule of law. Lawyers have a sacred duty to ensure that the impecunious and underprivileged citizens who live among them are not shut out from accessing justice because of their unfavourable position in the society. Lawyers in the country must therefore build a strong culture of pro bono.

The lawyer, as a professional bestowed with the techniques and procedures for accessing justice, has a privileged role and is peculiarly placed to give succour to the poor. That privileged should not be mismanaged. Legal aid institutions and the leadership of the organised bar have a major role to play as the coordinators of pro bono service delivery. Non-

${ }^{29}$ The report under reference was made in 2015 and considered the periods between $2013-2014$. 
governmental organisations, faith-based groups, recognised paralegals and law clinics should complement the effort of legal practitioners in the delivery of pro bono legal services. This is more so considering the fact that the professional ethics of lawyers, which put a limit to advertising and publicity in the course of legal practice, leave them at a disadvantage in sourcing for recipients of pro bono legal services. Lastly, all stakeholders in the justice sector including the investigators, the prosecutors, the adjudicators, the litigants and those in the bureaucracy must join hands to ensure that all challenges to pro bono engagement in the country are surmounted. 


\section{REFERENCES}

\footnotetext{
'Smith, R. H. (2010) Justice and the poor: a study of the present denial of justice to the poor and of the agencies making more equal their position before the law (1919). Kessinger Publishing, Montana, US., p. 3.

ii Tardi, C. (2019) What does pro bono really mean? Available at <http://www.investopedia.com/ ask/answers/ 08/pro-bono.asp> (accessed 27/3/2020).

iii Garner, B. A. (2004) Black's law dictionary ( $8^{\text {th }}$ edn). Thompson West, St. Paul, Minnesota, US., pp. $1240-$ 1241.

iv Daly, A. (2018) A brief history of pro bono (Pt. 1). King County Bar Bulletin. Available at <kcba.org/ForLawyers/ Bar-Bulletin/Postld/493/a-brief-history-of-pro-bono-part-one> (accessed 22/3/2020).

${ }^{v}$ Bellusci, M. E. (2014) The Tradition of Pro Bono Representation. Available at <http://www.needles.com/tradition-of-pro-bono-representation/> (accessed 22/3/2020).

${ }^{v i}$ Khadar, L. (2019) Expanding access to justice: an exploration of large firm pro bono practice across Europe (Unpublished Ph. D Thesis submitted to the Department of Law of the European University Institute, Florence, Italy) p. 100.

vii Gordon, R. W. (2019) Lawyers, the legal profession and access to justice in the United States: a brief history. Available at <http://www.amacad.org/publication/lawyers-legal-profession-access-justice-united-states-briefhistory> (accessed 22/3/2020).

viii Seipp, J. D. (2018) Legal services for the poor in early Common Law in Baker, T. R. (ed) Law and Society in Later Medieval England and Ireland: Essays in Honour of Paul Brand. Routledge, London, UK.

${ }^{\mathrm{ix}}$ Roger Williams University School of Law (2019) The history of lawyer pro bono services. Available at <http://www.law.rwu.edu/library/blog/history-lawyer-pro-bono-services > (accessed 23/3/2020).

${ }^{x}$ Adetayo, A. D. (2019) The necessity for proactive pro bono services in Nigeria. Available at <http://www.lawaxis 360degree.com/2019/06/05/the-necessity-for-proactive-pro-bono-services-innigeria/amp/> (accessed 24/3/2020).

${ }^{\mathrm{xi}}$ United Nations Office on Drugs and Crime (2011), Access to legal aid in criminal justice systems in Africa: survey report. United Nations, New York, p. 3.

xii Legal Aid Council of Nigeria, A historical profile of the Legal Aid Council of Nigeria. Available at $<$ http://www.legalaidcouncil. gov.ng/index.php?option=com content\&view=article\&id=11:fidanigeria\&lang=en $>$ (accessed 30/3/2020).

xiii Latham and Walkins LLP (2015), Pro bono practice and opportunities in Nigeria. Available at <http://www.Iw.com/admin/Upload/Documents/Global\%20Pro\%20Bono\%20survey/pro-bono-in-nigeria.pdf> (accessed 30/3/2020).

${ }^{x i v}$ Amnesty International (2008), Nigeria: prisoners' rights systematically flouted. Available at <http://www.amnesty.org/en/documents/afr44/001/2008/en/> (accessed 31/3/2020).

${ }^{x v}$ Legal Aid Council of Nigeria, LACON Profile: Legal Aid Council. Available at <http://www.legalaidcouncil. gov.ng/ index.php?option=com_content\&view=article\&id=208\&ltemid=2001\&lang=en $>$ (accessed 31/3/2020).
} 